B 103

\title{
ハニカム成形時の粘土流れの可視化
}

水谷 圭祐 ${ }^{\circ}$, 光木功次郎, 中西 友彦（（株）日本自動車部品総合研究所）

\section{Visualization of extruded clay flows of monolithic honeycombs}

\author{
Keisuke MIZUTANI , Kojiro MITUKI and Tomohiko NAKANISHI
}

\begin{abstract}
We visualized the clay flows of monolithic honeycombs in the extruded process 3-dimensionally with one parallel beam light source using several tools as follows.

(1) Transparent clasp made of resin

(2) Transparent silicon compounds instead of a real clay

(3) Silicone carbide particles as a tracer

Observing the real tracer and the shadow of the tracer simultaneously, we found that

1) Clay flows towards a center of a clasp from a edge of the one

2) Clay flows in parallel inside clasp

3) Clay moves from the die side to the clasp side as it flows towards a center of clasp Keywords: Visualization, Clay flow
\end{abstract}

\section{1. 緒 論}

押出し成形は押出し機前面に取り付けた金型を通して 原料を連続的に押出すことから量産性に優れ、各種のフ イルタの製作に応用されている。八ニカムは薄い壁に取 り囲まれた多くの貫通孔が整然と蜂の单状に並んでいる 成形体であり、貫通孔の形状には三角形、四角形、六角 形など種々の形状がある。一般的には正方形が主流なの で、今回は正方形のハニカムについて検討した。

押出し成形法にてハニカムを成形する時に粘土の流れ を可視化することで、ハニカムの曲がりや外周部の不具 合をなくすための指針を得ることを目的として、可視化 手法を検討した。

\section{2. 実 験}

\section{1 構 成}

押出し装置は、小型でも押出し成形が可能なプランジ ヤー式を採用した。(図 1)

金型は耐圧の点で通常の金属金型を使用する。口金は 粘土の流れを観察できるように透明樹脂を選定した。粘 土は可視化のために、実際の粘土と同等の粘弾性をむち 透明なシリコーンコンパウンドを選び、トレーサとして 平均粒径 $45 \mu \mathrm{m}$ の炭化珪素粒子を選定した。

下と横からの 2 台のカメラを使って 3 次元情報を得上 うとしたが、プランジャー式押出し成形機のスペースの 関倸で 1 台しかカメラが設置できないことが判明した。

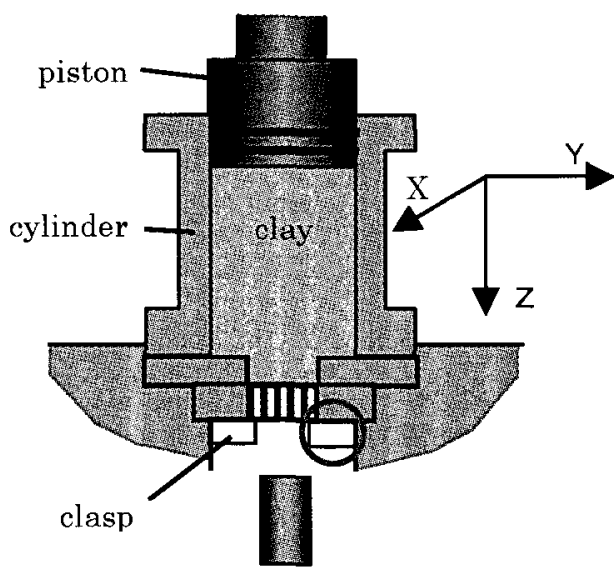

extruded monolithic honeycomb

Fig 1. Extruder of plunger procedure 特に押出しされる方向（Z 軸方向）の情報が測定でき ないことがわかったが、平行光線とマーカの影を使って 一方向からの観察で 3 次元情報を得る践成上した。

\section{2 光源のコリメート化と 3 次元データ解析}

一方向からの観察で 3 次元データを取得するために、 $45^{\circ}$ の角度で入射したコリメート光でできたトレーサ の影を下方から撮影した。マーカ実像と影間の距離の変 化(図中 $\mathrm{A}, \mathrm{B}$ )を測定することで $\mathrm{Z}$ 軸方向の情報を得るこ とができ、実像の $\mathrm{X}, \mathrm{Y}$ 軸方向の情報と合わせ 3 次元デー タとした。(図 2) 
光源のコリメート化のために、メタハライド光源 (250W) をピンホール板をはさむ $2 つ$ ๖クロマティ ックレンズを通過させることで実現した。（図 3）

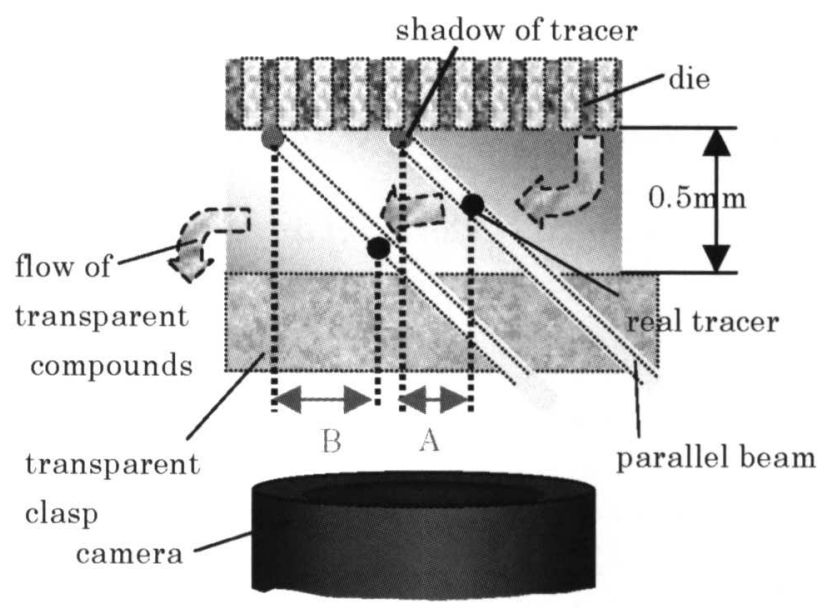

Fig2. Method of observing real tracer and shadow

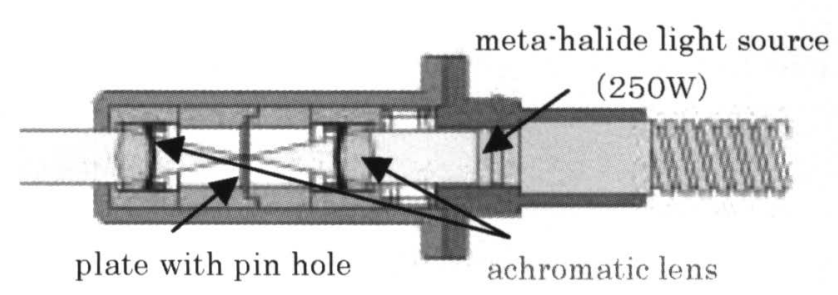

Fig3. Schematic image of pallarel beam 得られた画像の解析は自社内製ソフトを使用した。

\section{3 . 結 果}

図 4 に代表的な撮影結果を示す。

格子状に見えるものが金型で黒く見える箇所が粘土が通 過するスリット部である。一定間隔でトレーサ実像を追 った軌跡をカラーポイントで表記させている。

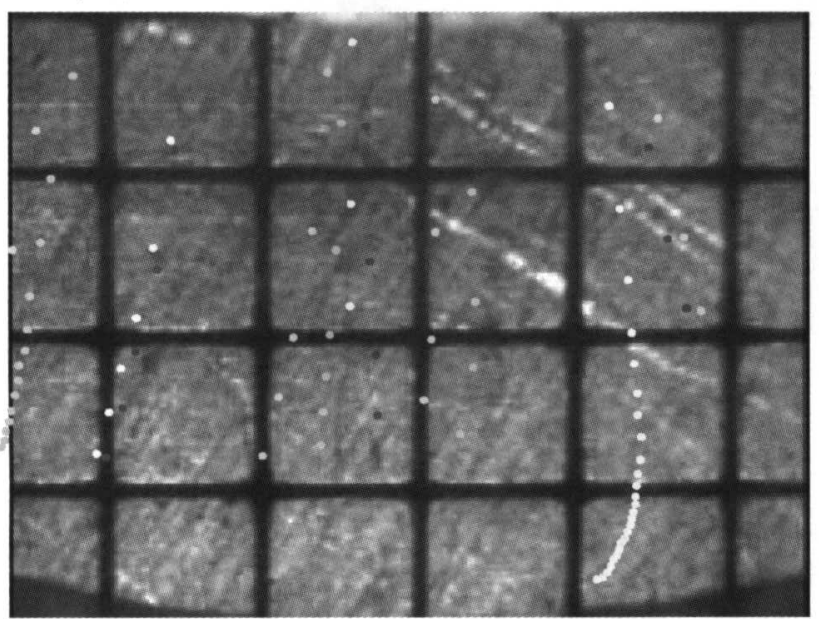

Fig4. Example of observing real tracer

図 4 の下部が金型の端で上部が金型中央方向になる。 粘土は金型の中心方向に向かって流れ、さらに金型の端
から内側に向かって粒子間隔が広くなっている（流速が 速くなる）ことがわかる。

図 5 には金型の格子方向におけるトレーサの 3 次元の 軌跡を示す。

$\mathrm{X}-\mathrm{Y}$ 面情報から、粘土は口金の中心方向に流れること がわかる。

X-Z 面情報から、粘土は口金の中心に向かって、金型 側から口金側に移行することがわかる。
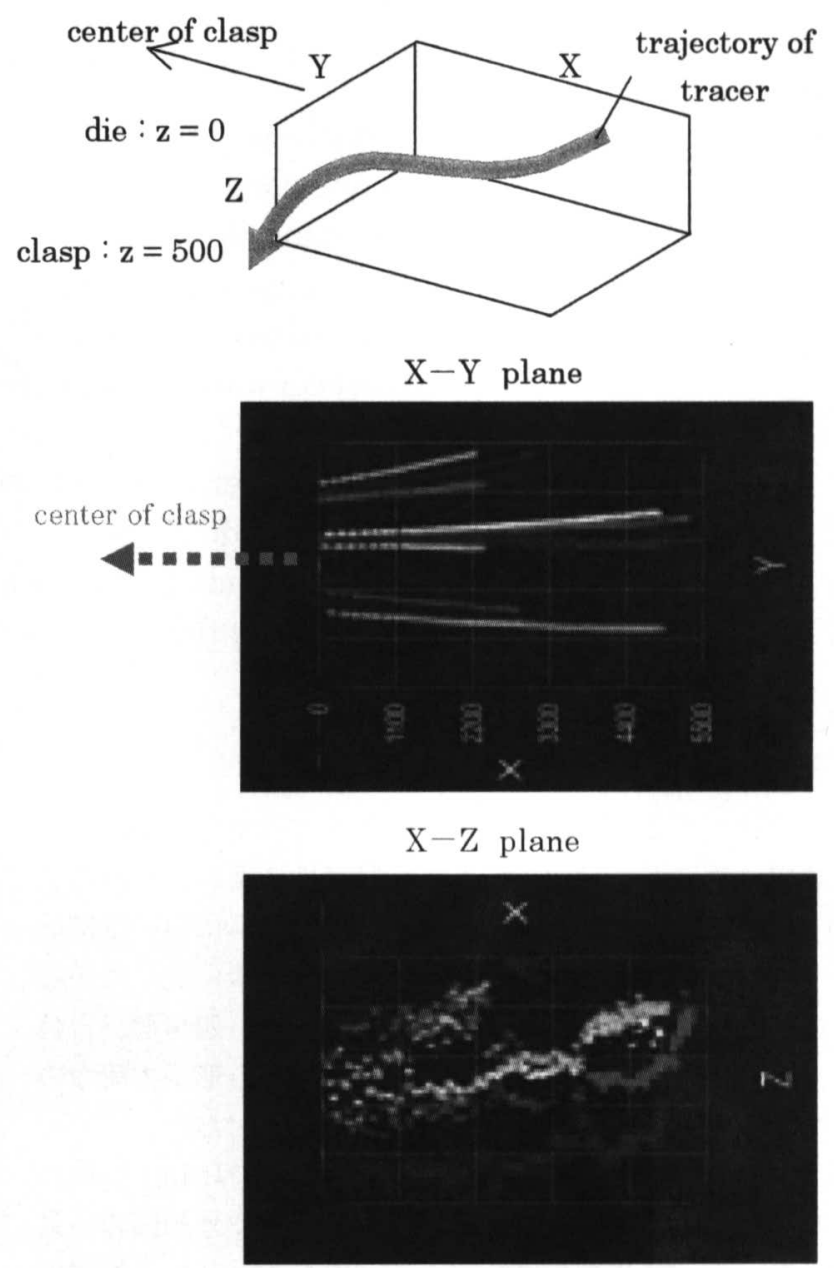

Fig5. Results of analysis

\section{4. 結 論}

1) シリコーンコンパウンド中に炭化珠素粒子を添加 した透明粘土を使って、ハニカム成形時の粘土流れ を可視化した。

2）一つのカメラで 3 次元情報を入手する手法を開発 した。

3）粘土は口金の中心に向かって、金型側から口金側 に移行しながら流れることがわかった。 